Jurnal Teknologi Informasi dan Manajemen

Edisi 1, Volume 1, Bulan Juli, Tahun 2018. E-ISSN 2622-2647

\title{
ANALISIS PREFERENSI KONSUMEN DI KOTA BANDUNG TERHADAP ATRIBUT PRODUK TELEVISI BERBAYAR TAHUN 2018
}

\author{
Dewinta Srinanda a, Ati Mustikasari ${ }^{b}$ \\ Program Studi D3 Manajemen Pemasaran, Fakultas IImu Terapan, Universitas Telkom

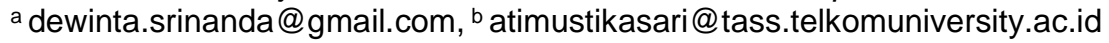

\begin{abstract}
The growth rate of pay TV customers has been delayed compared to the current population in Indonesia, so an appropriate strategy is needed to increase growth. With more intelligent consumers in Indonesia, companies increasingly need to know consumer preferences that can affect them, especially those related to product attributes in making purchases, especially Pay TV products. The purpose of this study is to find out consumer preferences, especially in Bandung, which is related to the attributes of pay TV products. Data collection techniques in this study using a questionnaire given to 100 respondents who know about pay TV products. The data obtained is processed using Conjoin Analysis. Product attributes in this study are types of subscription offers, number of channels, image quality, features, and prices. The results of this study illustrate that the price variable becomes the first or most important preference for consumers for pay TV products, and the smallest importance is the features offered.
\end{abstract}

Keywords: conjoint, product attributes, consumer preferences

Abstrak: Tingkat pertumbuhan pelanggan TV berbayar mengalami keterlambatan jika dibandingkan dengan jumlah penduduk di Indonesia saat ini, sehingga diperlukan sebuah strategi yang tepat untuk dapat meningkatkan pertumbuhannya. Dengan semakin cerdasnya konsumen di Indonesia, maka perusahaan semakin perlu untuk mengetahui preferensi konsumen yang dapat mempengaruhi mereka terutama yang berkaitan dengan atribut produk dalam melakukan pembelian terutama produk TV berbayar. Tujuan dari penelitian ini adalah untuk mengetahui preferensi konsumen khususnya di Kota Bandung yang berkaitan dengan atribut produk TV berbayar. Teknik pengumpulan data pada penelitian ini menggunakan kuesioner kepada 100 responden yang mengetahui mengenai produk TV berbayar. Data yang diperoleh diolah dengan menggunakan Analisis Konjoin. Atribut produk dalam penelitian ini adalah jenis penawaran berlangganan, jumlah saluran, kualitas gambar, fitur, dan harga. Hasil dari penelitian ini menggambarkan bahwa variabel harga menjadi preferensi pertama atau yang paling penting bagi konsumen untuk produk TV berbayar, dan yang paling kecil nilai kepentingannya adalah fitur yang ditawarkan.

Kata Kunci: konjoin, atribut produk, preferensi konsumen

\section{PENDAHULUAN}

Pertumbuhan pelanggan televisi berbayar di Indonesia sepanjang 2011-2016 rata -rata mencapai $26,7 \%$ per tahun. Dengan pertumbuhan tersebut, jumlah pelanggan TV berbayar Indonesia saat ini mencapai sekitar 3 juta. Padahal di negeri ini terdapat sekitar 65 juta rumah tangga, dan 36 juta di antaranya bisa dijadikan pelanggan [1]. Namun yang terjadi saat ini adalah industri Televisi bebayar di Asia Pasifik mengalami perlambatan pertumbuhan. Hal ini disebabkan oleh perlambatan pertumbuhan ekonomi di masing- 


\section{Jurnal Teknologi Informasi dan Manajemen}

Edisi 1, Volume 1, Bulan Juli, Tahun 2018. E-ISSN 2622-2647

masing negara. Perlambatan pertumbuhan jumlah pelanggan televisi berbayar juga terjadi di Hong Kong, Malaysia, dan Singapura [2].

Bandung merupakan salah satu kota besar di Indonesia dan saat ini pertumbuhan ekonomi kota Bandung mengalami peningkatan. Pengamat ekonomi dari Universitas Pasundan, Acuviarta Kartabi mengungkapkan, jika dibandingkan dengan nasional, rata - rata pertumbuhan ekonomi kota Bandung bisa dibilang tinggi. Alasannya, dipengaruhi oleh jumlah penduduk, sehingga Bandung menjadi pusat transaksi ekonomi [3]. Bandung menjadi salah satu target pasar yang menjanjikan bagi industri televisi berbayar karena pertumbuhan ekonomi dan penduduk kota Bandung yang meningkat. Pernyataan ini semakin jelas karena Rika Sumantri selaku Head of Marketing Communication Transvision menyatakan hal yang serupa.

Akan tetapi, bisnis televisi berbayar sedang menurun saat ini selain diakibatkan oleh perlambatan pertumbuhan ekonomi nasional, persaingan yang ketat antar perusahaan penyedia televisi berbayar pun menjadi kendala dalam pertumbuhan industri ini. Bila perusahan mengetahui preferensi (kecenderungan) konsumen terhadap atribut produk televisi berbayar maka perusahaan akan unggul dalam berkompetisi dalam industri ini. Adapun atribut produk televisi berbayar adalah tipe tawaran berlangganan, harga, fitur, kualitas gambar, dan jumlah channel. Perusahan dapat menawarkan produk yang benar benar dibutuhkan dan diinginkan oleh konsumen. Konsumen pun akan dengan senang hati memilih dan menggunakan produk dari perusahaan. Tujuan penelitian ini untuk mengetahui preferensi konsumen terhadap produk pay TV berdasarkan masing - masing atribut dan untuk mengetahui profil ideal pay TV yang diinginkan konsumen.

\section{TINJAUAN PUSTAKA}

Di dalam sebuah penelitian membutuhkan beberapa tinjauan pustaka, berikut tinjauan pustaka untuk penelitian ini.

\subsection{Pemasaran}

Definisi pemasaran menurut Kotler dan Keller merupakan sebuah proses sosial dimana orang-orang dan kelompok memperoleh apa yang mereka butuhkan dan inginkan melalui penciptaan, penawaran, serta pertukaran manfaat produk dan jasa secara bebas dengan yang lainnya. Jadi, pemasaran adalah suatu proses dalam memperoleh pertukaran manfaat sehingga dapat memenuhi kebutuhan dan keinginannya [4].

\subsection{Manajemen Pemasaran}

Menurut Kotler dan Armstrong, manajemen pemasaran adalah seni dan ilmu dalam memilih target pasar, dan mendapatkan, menjaga serta menumbuhkan pelanggan melalui penciptaan, penyampaian dan pengkomunikasian nilai superior kepada pelanggan [5].

\subsection{Perilaku Konsumen}

Menurut Priansa, perilaku konsumen adalah perilaku yang ditampilkan oleh konsumen saat mereka mencari, membeli, menggunakan, mengevaluasi, dan menghabiskan produk dalma rangka memenuhi kebutuhan dan keinginannya [6].

\subsection{Preferensi Konsumen}

Menurut Simamora, preferensi konsumen adalah konsep abstrak yang menggambarkan peta peningkatan kepuasan yang diperoleh dari kombinasi barang dan jasa sebagai cermin 


\section{Jurnal Teknologi Informasi dan Manajemen}

Edisi 1, Volume 1, Bulan Juli, Tahun 2018. E-ISSN 2622-2647

dari selera pribadinya [7]. Berdasarkan pengertian diatas, preferensi konsumen adalah sikap kecenderungan konsumen baik positif maupun negatif dalam memilih suatu produk.

\subsection{Produk}

Menurut Kotler dan Armstrong, produk adalah segala sesuatu yang dapat ditawarkan oleh perusahaan kepada suatu pasar untuk menarik perhatian, mengambil alih, penggunaan atau konsumsi yang mungkin memuaskan keinginan atau kebutuhan [5].

\subsection{Atribut Produk}

Menurut Kotler dan Armstrong, mengembangkan suatu produk atau jasa perlu menentukan manfaat yang akan ditawarkan. Manfaat - manfaat ini dikomunikasikan dan disampaikan melalui atribut - atribut produk seperti kualitas, fitur, style dan desain [5]. Indikator yang digunakan sebagai alat pengukuran variabel dalam penelitian ini didapat dari penelitian terdahulu dan saran dari perusahaan. Dalam teknik analisis konjoin, indikator penelitian disebut dengan atribut dan bagian dari atribut disebut dengan level. Tabel 1 merupakan atribut dalam penelitian ini.

Tabel 1

Atribut dan level penelitian

\begin{tabular}{|c|c|c|}
\hline No & Atribut Penelitian & Level Atribut \\
\hline \multirow{3}{*}{1} & \multirow{3}{*}{ Tawaran Berlangganan } & All Channel \\
\hline & & Ala Carte \\
\hline & & Pay per View \\
\hline \multirow{3}{*}{2} & \multirow{3}{*}{ Jumlah Channel } & $<75$ \\
\hline & & $75-100$ \\
\hline & & $>100$ \\
\hline \multirow{2}{*}{3} & \multirow{2}{*}{ Kualitas Gambar } & HD \\
\hline & & SD \\
\hline \multirow{2}{*}{4} & \multirow{2}{*}{ Fitur } & Interactive \\
\hline & & Non Interactive \\
\hline \multirow{3}{*}{5} & \multirow{3}{*}{ Harga } & $<$ Rp. $150,000.00$ \\
\hline & & Rp. $150,000.00$ - Rp. $250,000.00$ \\
\hline & & $>$ Rp. $250,000.00$ \\
\hline
\end{tabular}

Sumber: Hasil olah data Penulis (2018)

\section{METODE PENELITIAN}

Menurut Sugiyono, terdapat dua metode penelitian yaitu Kuantitatif dan Kualitatif [8]. Secara umun metode penelitian diartikan sebagai cara ilmiah untuk mendapatkan data dengan tujuan dan kegunaan tertentu. Penelitian ini menggunakan metode kuantitatif karena data pada penelitian ini berupa angka sebab menggunakan kuesioner untuk mengetahui pendapat responden.

Kerangka pemikiran dibutuhkan agar hubungan antara variabel independen dan dependen dapat terlihat jelas. Gambar 1 merupakan kerangka pemikiran dalam penelitian ini. 


\section{Jurnal Teknologi Informasi dan Manajemen}

Edisi 1, Volume 1, Bulan Juli, Tahun 2018. E-ISSN 2622-2647

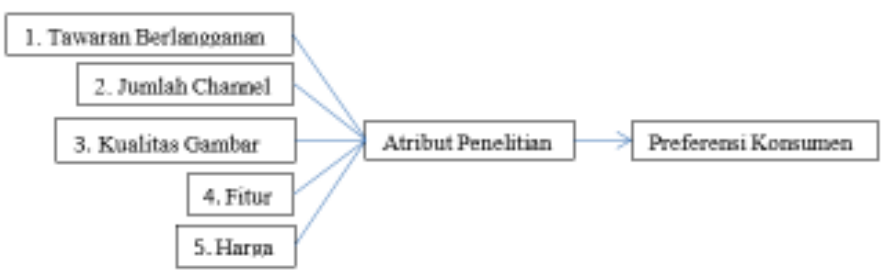

Sumber: Hasil olah data Penulis (2018)

\section{Gambar 1}

Kerangka pemikiran

Penelitian terdahulu digunakan sebagai acuan dalam mengerjakan penelitian. Dalam penelitian ini, penelitian terdahulu digunakan sebagai salah satu acuan dalam menentukan atribut penelitian. Tabel 2 merupakan penelitian terdahulu yang digunakan dalam penelitian ini.

Tabel 2

Penelitian terdahulu

\begin{tabular}{|c|c|c|c|c|c|c|}
\hline Tipe & $\begin{array}{c}\text { Nama } \\
\text { peneliti }\end{array}$ & $\begin{array}{c}\text { Judul } \\
\text { penelitian }\end{array}$ & Atribut & $\begin{array}{c}\text { Teknik } \\
\text { analisis } \\
\text { data }\end{array}$ & Hasil penelitian & $\begin{array}{l}\text { Hubungan } \\
\text { dengan } \\
\text { penelitian }\end{array}$ \\
\hline Skripsi & $\begin{array}{l}\text { Muhammad } \\
\text { Dary } \\
\text { Fauzan } \\
(2018)\end{array}$ & $\begin{array}{l}\text { Perancangan } \\
\text { Atribut Kafe } \\
\text { Yelloe Truck } \\
\text { berdasarkan } \\
\text { preferensi } \\
\text { konsumen } \\
\text { Kafe Bandung } \\
\text { dengan } \\
\text { menggunakan } \\
\text { metode } \\
\text { konjoin }\end{array}$ & $\begin{array}{ll}\text { 1. } & \text { Harga } \\
\text { 2. } & \text { Produk } \\
\text { 3. } & \text { Fasilitas } \\
\text { 4. } & \text { Promosi } \\
\text { 5. } & \text { Atmosfir }\end{array}$ & $\begin{array}{l}\text { Analisis } \\
\text { Konjoin }\end{array}$ & $\begin{array}{l}\text { Berdasarkan skor } \\
\text { kepentingan dan kegunaan, } \\
\text { berikut urutan preferensi } \\
\text { konsumen: } \\
\text { 1. Harga: Rp. } 5.000 \text { - Rp. } \\
30.000 \\
\text { 2. Produk: Rasa } \\
\text { 3. Fasilitas: Wifi Kencang } \\
\text { 4. Promosi: Buy One Get } \\
\text { One } \\
\text { 5. Atmosfir: Kebersihan } \\
\text { Kafe }\end{array}$ & $\begin{array}{l}\text { Persamaan: } \\
\text { 1. Menggunakan } \\
\text { metode analisis } \\
\text { yang sama } \\
\text { yaitu analisis } \\
\text { konjoin. } \\
\text { 2. Tempat } \\
\text { Penelitian di } \\
\text { Kota Bandung. } \\
\text { Perbedaan: } \\
\text { Objek Penelitian } \\
\text { merupakan kafe }\end{array}$ \\
\hline
\end{tabular}




\section{Jurnal Teknologi Informasi dan Manajemen}

Edisi 1, Volume 1, Bulan Juli, Tahun 2018. E-ISSN 2622-2647

\begin{tabular}{|c|c|c|c|c|c|c|}
\hline Tipe & $\begin{array}{c}\text { Nama } \\
\text { peneliti }\end{array}$ & $\begin{array}{c}\text { Judul } \\
\text { penelitian }\end{array}$ & Atribut & $\begin{array}{c}\text { Teknik } \\
\text { analisis } \\
\text { data }\end{array}$ & Hasil penelitian & $\begin{array}{c}\text { Hubungan } \\
\text { dengan } \\
\text { penelitian }\end{array}$ \\
\hline Skripsi & $\begin{array}{l}\text { Desti } \\
\text { Supianti } \\
\text { (2015) }\end{array}$ & $\begin{array}{l}\text { Analisis } \\
\text { Preferensi } \\
\text { Konsumen } \\
\text { Dalam } \\
\text { Memilih } \\
\text { Produk } \\
\text { Televise } \\
\text { Berbayar Di } \\
\text { Kota Bandung } \\
\text { Dengan } \\
\text { Menggunakan } \\
\text { Metode } \\
\text { Conjoint } \\
\text { Analysis } \\
\text { (Objek Studi: } \\
\text { Indovisision, } \\
\text { Top TV, } \\
\text { Okevision, } \\
\text { Firstmedia, } \\
\text { Dan } \\
\text { Transvision) }\end{array}$ & $\begin{array}{l}\text { 1. Harga } \\
\text { 2. Jumlah } \\
\text { channel } \\
\text { 3. Kualitas } \\
\text { gambar } \\
\text { 4. Teknologi } \\
\text { 5. Tawaran } \\
\quad \text { berlangganan } \\
\text { 6. Media } \\
\text { 7. Fitur }\end{array}$ & $\begin{array}{l}\text { Analisis } \\
\text { Conjoint }\end{array}$ & $\begin{array}{l}\text { 1. Konsumen menginginkan } \\
\text { channel yang lengkap } \\
\text { 2. Konsumen menginginkan } \\
\text { harga produk <Rp. } \\
200.000,00 \\
\text { 3. Konsumen mengingkan } \\
\text { channel dengan jumlah > } \\
100 \\
\text { 4. Konsumen menginginkan } \\
\text { kualitas tyangan HD, } \\
\text { teknologi satelit, dan fitur } \\
\text { interaktif. }\end{array}$ & $\begin{array}{l}\text { Persamaan: } \\
\text { 1. Persamaan } \\
\text { terletak pada } \\
\text { objek } \\
\text { penelitianyang } \\
\text { nyaris sama } \\
\text { yakni pay TV. } \\
\text { 2. Menggunakan } \\
\text { metode analisis } \\
\text { conjoin } \\
\text { Perbedaan: } \\
\text { Perusahaan yang } \\
\text { menjadi objek } \\
\text { berbeda. }\end{array}$ \\
\hline Skripsi & $\begin{array}{l}\text { Ismi F } \\
\text { Sasmita } \\
\text { (2013) }\end{array}$ & $\begin{array}{l}\text { Analisis } \\
\text { Konjoin } \\
\text { Metode } \\
\text { Traditional } \\
\text { Full Profile } \\
\text { Untuk } \\
\text { Mengetahui } \\
\text { Preferensi } \\
\text { Konsumen } \\
\text { Wanita } \\
\text { Terhadap } \\
\text { Notebook di } \\
\text { Kota Bandung }\end{array}$ & $\begin{array}{l}\text { 1. Harga } \\
\text { 2. Merek } \\
\text { 3. Warna } \\
\text { 4. Kapasitas } \\
\text { Hard Disk } \\
\text { 5. Operating } \\
\text { system } \\
\text { 6. Memori } \\
\text { RAM }\end{array}$ & $\begin{array}{l}\text { Analisis } \\
\text { Konjoin }\end{array}$ & \begin{tabular}{|l} 
1. Urutan Atribut \\
Berdasarkan nilai \\
kepentingannya: Harga, \\
Warna, memori RAM, \\
Kapasitas Hard Disk, \\
Operating System, dan \\
Merek. \\
2. Urutan Level Yang \\
disukai adalah: \\
a. Harga dibawah \\
sepuluh juta \\
b. Berwarna \\
c. Kapasitas Ram 8 GB \\
d. Kapasitas HARd Disk \\
500 Gb \\
e. Operating System \\
Windows 7 \\
f. Brand Asing
\end{tabular} & $\begin{array}{l}\text { Persamaan: } \\
\text { 1. Metode } \\
\text { penelitian yang } \\
\text { digunakan } \\
\text { sama yakni } \\
\text { metode } \\
\text { analisis konjoin } \\
\\
\text { Perbedaan: } \\
\text { 1. Objek } \\
\text { penelitian } \\
\text { berbeda yakni } \\
\text { Notebook }\end{array}$ \\
\hline Skripsi & $\begin{array}{l}\text { Muhammad } \\
\text { Dary } \\
\text { Fauzan } \\
(2018)\end{array}$ & $\begin{array}{l}\text { Perancangan } \\
\text { Atribut KAfe } \\
\text { Yelloe Truck } \\
\text { Berdasarkan } \\
\text { Preferensi } \\
\text { konsumen } \\
\text { KAfe } \\
\text { Bandung } \\
\text { Dengan } \\
\text { Menggunakan } \\
\text { Metode } \\
\text { Konjoin }\end{array}$ & $\begin{array}{ll}\text { 1. } & \text { Harga } \\
\text { 2. } & \text { Produk } \\
\text { 3. } & \text { Fasilitas } \\
\text { 4. } & \text { Promosi } \\
\text { 5. } & \text { Atmosfir }\end{array}$ & $\begin{array}{l}\text { Analisis } \\
\text { Konjoin }\end{array}$ & $\begin{array}{l}\text { Berdasarkan skor } \\
\text { kepentingan dan kegunaan, } \\
\text { berikut urutan preferensi } \\
\text { konsumen: } \\
\text { 1. Harga: Rp. } 5.000-\mathrm{Rp} . \\
30.000 \\
\text { 2. Produk: Rasa } \\
\text { 3. Fasilitas: Wifi Kencang } \\
\text { 4. Promosi: Buy One Get } \\
\text { One } \\
\text { 5. Atmosfir: Kebersihan } \\
\text { Kafe }\end{array}$ & $\begin{array}{l}\text { Persamaan: } \\
\text { 1. Menggunakan } \\
\text { metode } \\
\text { analisis yang } \\
\text { sama yaitu } \\
\text { analisis } \\
\text { konjoin. } \\
\text { 2. Tempat } \\
\text { Penelitian di } \\
\text { Kota } \\
\text { Bandung. } \\
\\
\text { Perbedaan: } \\
\text { Objek Penelitian } \\
\text { merupakan kafe }\end{array}$ \\
\hline
\end{tabular}

Sumber: Hasil olah data Penulis (2018)

Teknik pengumpulan data menggunakan kuesioner, studi pustaka, dan observasi. Populasi yang diteliti adalah masyarakat kota Bandung yang menggunakan televisi 


\section{Jurnal Teknologi Informasi dan Manajemen}

Edisi 1, Volume 1, Bulan Juli, Tahun 2018. E-ISSN 2622-2647

berbayar, jumlah sampel minimal berjumlah 97 yang didapat dari rumus Bernoulli, teknik sampling adalah non probability sampling dengan cara purposive.

Teknik analisis data yang digunakan adalah analisis konjoin, sedangkan teknik pengujian data menggunakan uji validitas, uji realibilitas, dan uji korelasi. Analisis konjoin adalah suatu teknik multivariat yang khusus digunakan untuk memahami bagaimana responden mengembangkan preferensi terhadap suatu produk atau jasa [9]. Terdapat tujuh tahapan analisis konjoin, yaitu:

1. Menetapkan tujuan konjoin.

2. Mendesain analisis konjoin.

3. Asumsi analisis konjoin.

4. Estimasi model konjoin.

5. Interpretasi hasil.

6. Validasi hasil konjoin.

7. Pengaplikasian hasil konjoin.

\section{PEMBAHASAN DAN HASIL PENELITIAN}

\subsection{Karakteristik Responden}

Responden berjenis kelamin wanita mendominasi jumlah responden dalam penelitian ini sebesar $72 \%$. Rentang umur yang mendominasi adalah 20-24 tahun dengan jumlah tiga puluh delapan responden. $39 \%$ responden memiliki pendapatan yang berkisaran antara Rp.2.500.000-Rp.5.000.000. Pegawai swasta mendominasi jumlah responden dalam penelitian ini sebesar $40 \%$. Responden yang menonton $>3$ jam sehari sebesar $37 \%$ atau berjumlah tiga puluh tujuh. Mayoritas responden menonton jenis channel film dengan persentase sebesar $31 \%$ atau berjumlah tiga puluh satu, disusul dengan hiburan sebesar $26 \%$ atau berjumlah dua puluh enam, berita sebesar $12 \%$ atau sebesar dua belas. tujuh puluh empat responden mengaku jenuh dengan konten televisi free to air, mayoritas responden telah berlangganan televisi berbayar yang saat ini digunakan selama lebih dari 3 tahun.

Berdasarkan hasil karakteristik responden, selama lebih dari tiga tahun wanita berumur 20-24 tahun yang bekerja sebagai pegawai swasta menghabiskan lebih dari tiga jam sehari untuk menonton televisi berbayar. Channel yang disukainya adalah film, hiburan, dan berita. Dengan pendapatan antara Rp.2.500.000-Rp.5.000.000 responden memutuskan untuk berlangganan televisi berbayar. Mayoritas responden jenuh dengan konten televisi free to air sehingga mereka beralih ke televisi berbayar.

\subsection{Analisis Preferensi Konsumen terhadap Televisi Berbayar}

Berdasarkan Tabel 3, importance values harga adalah sebesar 25,018\%. Tawaran (berlangganan) sebesar 24,473\%, (jumlah) Channel sebesar 23,159\%, (kualitas) Gambar $13,945 \%$, dan Fitur televisi berbayar yaitu sebesar 13,404\%.

Berdasarkan utilities value pada Tabel 3 , masing - masing atribut memiliki level dengan nilai tertinggi, yaitu: Tawaran Berlangganan All Channel, jumlah channel lebih dari 100, Kualitas gambar HD, Fitur Non Interaktif, dan Harga yang berkisar dari Rp. 150.000 - Rp. 250.000 . 


\section{Jurnal Teknologi Informasi dan Manajemen}

Edisi 1, Volume 1, Bulan Juli, Tahun 2018. E-ISSN 2622-2647

Tabel 3

Nilai Kegunaan Level dan Nilai Kepentingan Atribut

\begin{tabular}{|c|c|c|c|c|}
\hline \multirow{2}{*}{ Atribut Produk } & \multicolumn{3}{|c|}{ Utilities } & \multirow[t]{2}{*}{ Importance Values } \\
\hline & Level & Utility Estimate & Std. Error & \\
\hline \multirow{3}{*}{ Tawaran } & All Channel & .031 & .078 & \multirow{3}{*}{24.473} \\
\hline & Ala Carte & -.033 & .092 & \\
\hline & Pay Per View & .002 & .092 & \\
\hline \multirow{3}{*}{ Channel } & $<75$ & .033 & .078 & \multirow{3}{*}{23.159} \\
\hline & $75-100$ & -.095 & .092 & \\
\hline & $>100$ & .063 & .092 & \\
\hline \multirow{2}{*}{ Gambar } & $\mathrm{HD}$ & .146 & .059 & \multirow{2}{*}{13.945} \\
\hline & SD & -.146 & .059 & \\
\hline \multirow{2}{*}{ Fitur } & Interaktif & -.113 & .059 & \multirow{2}{*}{13.404} \\
\hline & Non Interaktif & .113 & .059 & \\
\hline \multirow{3}{*}{ Harga } & $<$ Rp. 150.000 & -.003 & .078 & \multirow{3}{*}{25.018} \\
\hline & $\begin{array}{l}\text { Rp. } 150.000 \text { - Rp. } \\
250.000\end{array}$ & .014 & .092 & \\
\hline & > Rp. 250.000 & -.011 & .092 & \\
\hline & stant) & 4.125 & .068 & \\
\hline
\end{tabular}

Sumber: Hasil olah data menggunakan SPSS

\section{KESIMPULAN}

Berdasarkan pembahasan hasil penelitian dalam poinsebelumnya terdapat informasi preferensi konsumen terhadap atribut televisi berbayar di kota bandung yang terlihat dari nilai kepentingan atribut dan nilai kegunaan level. Bila diurutkan maka akan menghasilkan kombinasi seperti berikut.

a. Harga dengan importance values $25,018 \%$. Level yang dipreferensikan konsumen adalah Rp. 150.000 - Rp. 250.000 dengan utilities score 0,014.

b. Tipe Tawaran Berlangganan dengan importance values $24,473 \%$. Level yang dipreferensikan konsumen adalah all channel dengan utilities score 0,031 .

c. Jumlah channel dengan importance values $23,159 \%$. Level yang dipreferensikan konsumen adalah jumlah channel lebih dari 100 dengan utilities score 0,063.

d. Kualitas gambar dengan importance values $13,945 \%$. Level yang dipreferensikan konsumen adalah kualitas gambar HD dengan utilities score 0,146 .

e. Fitur dengan importance values $13,404 \%$. Level yang dipreferensikan konsumen adalah fitur non interaktif dengan utilities score 0,113 .

Rekomendasi yang disarankan kepada perusahaan adalah sebagai berikut.

a. Importance score atribut fitur dan kualitas gambar adalah yang terendah dibanding atribut penelitian lainnya, maka akan lebih baik bila ketika perusahaan menawarkan produk, perusahaan fokus pada atribut lain yang lebih tinggi importance score-nya dan akan dipreferensikan oleh konsumen.

b. Utilities score terendah dimiliki oleh level atribut: Tawaran Berlangganan Ala Carte, Jumlah channel 75 - 100, Kualitas gambar SD, Fitur Interaktif, dan Harga $<$ Rp. 150.000. Apabila kini perusahaan memiliki kombinasi paket seperti ini maka, akan lebih baik bila perusahaan menggunakan voucher dan souvenir untuk menarik minat beli konsumen.

c. Sebaiknya perusahaan memformulasikan paket basic baru dengan karakteristik yang disukai konsumen. Karena dengan begitu konsumen akan tertarik untuk berlangganan televisi berbayar. 


\section{Jurnal Teknologi Informasi dan Manajemen}

Edisi 1, Volume 1, Bulan Juli, Tahun 2018. E-ISSN 2622-2647

\section{REFERENSI}

[1] Wulandari, Dwi. 2016. Pertarungan di Pasat TV Berbayar. Indonesia: Mix. Tersedia: http://mix.co.id/headline/pertarungan-di-pasar-tv-berbayar

[2] Bhojwani, Lavina. 2016. Media Partners Asia: Industri TV berbayar di Asia Pasifik alami perlambatan pertumbuhan. Indonesia: Antara News. Tersedia: https://www.antaranews.com/berita/573318/media-partners-asia-industri-tvberbayar-di-asia-pasifik-alami-perlambatan-pertumbuhan

[3] Maynolitta. 2017. Bandung Menjadi Pusat Transaksi. Bandung: PRFM News. Tersedia:http://prfmnews.com/berita.php?detail=pertumbuhan-ekonomi-tinggibandung-jadi-pusat-transaksi

[4] Kotler, Philip and Kevin Lane Keller. (2016). Marketing Management. Edisi 15. Jakarta: Erlangga. New Jersey: Pearson Education.

[5] Kotler, Philip and Gary Armstrong. (2014). Principle of Marketing. 15th Edition. New Jersey: Pearson Prentice Hall.

[6] Priansa, Donni Juni. (2017). Perilaku Konsumen Dalam Persaingan Bisnis Kontemporer. Cetakan 1. Bandung: CV Alfabeta.

[7] Fauzan, Muhammad Dary. (2018). Perancangan Atribut Kafe Yellow Truck Berdasarkan Preferensi Konsumen Kafe Bandung Dengan Metode Konjoin. Bandung Telkom University.

[8] Sugiyono. (2015). Statistik Nonparametris Untuk Penelitian. Bandung: CV Alfabeta

[9] Ghozali, Imam. (2016). Aplikasi Analisis Multivariate IBM SPSS 23. Cetakan VIII. Semarang: Badan Penerbit Universitas Diponegoro 